\title{
The Ross Institute and Hospital for Tropical Diseases.
}

\section{$\mathrm{T}^{\mathrm{H}}$} twenty-fifth anniversary in 1923 of Sir Ronald Ross's epoch-making discovery of the transmission of human malaria through the bite of anopheline mosquitoes was the occasion of an appeal for the foundation of an institute for research upon, and for the treatment of, tropical diseases which should serve as a lasting monument to Ross's achievement.

As a result of this appeal, initiated by Sir William Simpson and Sir Aldo Castellani and supported by many influential signatories in all parts of the world, funds were contributed by Indian princes, colonial governments and municipalities, city companies, rubber, tea, oil, and other trading companies, and private individuals, a house and grounds were acquired on Putney Heath, London, and the building was adapted partly as a hospital for the treatment of patients suffering from tropical diseases and partly as laboratories for research. This constitutes the present Ross Institute and Hospital for Tropical Diseases, of which Her Grace the Duchess of Portland is president.

The Institute is administered by a council of which Sir Charles Campbell McLeod is chairman and Major Lockwood Stevens, secretary. The staff includes Sir Ronald Ross himself as director-in-chief ; Sir William Simpson, director of tropical hygiene; and Sir Aldo Castellani, medical director, with Sir Malcolm Watson in charge of the Malaria Department. The annual Report for 1930, recently issued, surveys at some length the activities and research work of the Institute. An increased number of patients were treated in the hospital during the year, the total number being 85 .
Sir Ronald Ross has continued to write upon malaria and its control, Sir William Simpson is investigating the longevity of the plague and other bacteria, and Sir Aldo Castellani has published several papers on minor and other ailments of the tropics and upon fungi which attack the skin. Dr. Shaw-Mackenzie is continuing his studies of the blood-changes that occur in eancer and on the diagnosis by blood-tests and treatment of this disease. In the malaria laboratory, observations have been made on the influence of cold upon the larvæ of the British tree-breeding anopheline, A. plumbeus, showing that they hibernate and resist even freezing in the water in the tree-holes. A lengthy survey is given of the activities of the Anti-Malaria Advisory Committee of the Institute in the control of mosquitoes and malaria abroad; this work was referred to in NATuRE of Jan. 31, p. 173.

Courses of instruction have been given to planters and others interested in the control of malaria. Unfortunately, the income for the year shows a decrease of $£ 1500$, partially counterbalanced by a reduction in expenditure of $£ 628$ on 1929 . The financial position of the Ross Institute is unsatisfactory, as at present the Institute is entirely dependent upon voluntary contributions, and an appeal is made for funds to create an endowment fund.

In a series of appendices, the malaria policy of the Ross Institute is outlined and the results of malariapreventive measures summarised. Mr. Jackson Clarke, a veteran worker in cancer research, is arranging his collection of slides and photographs for exhibition in the laboratories.

\section{Bi-Centenary of the Foundation of the Royal Dublin Society.}

$\mathrm{T}$ HE bi-centenary of the Royal Dublin Society will be celebrated in Dublin on June 23-26. The history of the Society is in many respects remarkable. As regards the scope of its activities it is probably unique. The first meeting of the Society was held on June 25, 1731, in the rooms of the Philosophical Society in Trinity College, Dublin. The earliest definition of its objects is expressed as follows :

"It was proposed and unanimously agreed unto, to form a Society, by the name of the Dublin Society, for improving Husbandry, Manufactures and other useful arts."

A few days later, on July 1, at the second meeting, it was agreed that the words " and sciences" should be added after "arts" in the title of the Society.

Among its earliest members the name of Thomas Prior appears. He had graduated in Trinity College, Dublin, in 1703. He acted as secretary of the young Society for twenty years, and is by many regarded as its founder. Several distinguished names appear as early members: among others, that of Dr. John Madden, whose son, Samuel Madden, D.D., became a member in 1733 and proved to be one of its most loyal, able, and generous supporters. He became known as "Premium Madden' because of his wise policy of offering premiums for methods of tillage, etc. $\mathrm{He}$ was influential in obtaining for the young Society its first charter.

Among the earliest members many other noteworthy names appear, including that of Sir Thomas Molyneux, a fellow of the Royal Society, who was a friend of Robert Boyle, of Sir William Petty, of Newton, Evelyn, Dryden, and Locke. Molyneux's scientific interests were wide; he first gave a rational account of the origin of the Giants' Causeway, and wrote a scientific report on the Irish elk. In general, however, matters of a practical character engaged the attention of the young Society: such as Prior's paper on "A New Method of Draining Marshy and Boggy Lands".

The foundation of local branch societies in the principal towns and cities of Ireland, which should establish communication with the Dublin Society, was promoted. There is no doubt as to the practical and directly beneficent character of the work of the young Society, and, at the same time, of its interest in the promotion of applied and general science.

This was in the days of that brilliant but unhappy genius, Jonathan Swift. A very extraordinary, anonymous book, printed in Dublin in 1753, and written "By a Friend to the Peace and Prosperity of Ireland ", is in the possession of the present writer. It purports to be "A Dialogue between Dean Swift and Thos. Prior, Esq., in the Isles of St. Patrick's Church, Dublin, Oct. 9, 1753 ". The shades of the two defunct speakers, rising at midnight from the grave, discuss the economic conditions of Ireland and how best they can be improved. The constructive ambitions of Prior are in general exposed to the caustic satire and pessimism of the Dean. But in the end both agree on the necessity of reforms. The dialogue, covering 134 pages, is brilliant throughout.

In the first century of the Society's existence, systematic works, not only of economic and practical nature, but also in many cases of considerable scientific interest, were published by the Society. The now wellknown 'Spring Shows' of the Society were inaugurated in 1831, and the stated meetings of the scientific members of the Society began some three years later.

It has been said that most of the good which has been done for Ireland has been done by this great

No. 3216, VoL. 127] 